\title{
latrogenic Right Subclavian Artery Giant Pseudoaneurysm in a 1-Year Old Case
}

Olgu Sunumu Case Report

Received/Geliş: 28.06.2020 Accepted/Kabul: 28.08.2020 First Online: 28.09 .2021

Ömer Faruk Gülaştı SBÜ. Erzurum Bölge Eğitim ve Araştırma Hastanesi, Çocuk Kalp ve Damar Cerrahisi, Atatürk Mahallesi Çat Yolu Cad. 25070 Yakutiye Erzurum, Türkiye drofg@hotmail.com ORCiD: 0000-0001-8019-5116

E.H. Yardımcı 0000-0002-3848-3605 $S B U ̈$. Erzurum Bölge Eğitim ve Araştırma Hastanesi, Gögüus Cerrahisi Kliniği, Erzurum, Türkiye

Cite as: Gülaştı ÖF, Yardımcı EH. latrogenic right subclavian artery giant pseudoaneurysm in a 1 -year old case. Tepecik Eğit. ve Araşt. Hast. Dergisi. 2021;31(3):432-5.

\section{Bir Yaşındaki Olguda İyatrojenik Dev Sağ Subklavyen Arter Psödoanevrizması}

Ömer Faruk Gülaştı ๑, Eyüp Halit Yardımcı ®

\begin{abstract}
Central venous punctures are performed frequently in pediatric intensive care units, but life threatening complications are rare due to these. A pseudoaneurysm was observed after 1 month following right subclavian puncture, in a 1-year old case, who has been followed at intensive care units since birth. Surgery was performed by modified 'trapdoor' incision as a combination of right supraclavicular and median sternotomy incisions to the case; suffering from right brachial plexus compression symptoms, diminished right arm arterial flow, and vena cava superior syndrome symptoms.
\end{abstract}

Keywords: Pseudoaneurysm, catheter, pediatric, subclavian artery

ÖZ

Santral venöz girişim çocuk yoğun bakım ünitelerinde sık olarak yapılmaktadır. Bu girişimlere bağlı hayatı tehdit edici komplikasyonlar nadiren meydana gelmektedir. Doğumundan itibaren yoğun bakım ünitesinde takip edilen 1 yaşındaki olguda, sağ subklavyen kateter girişiminden yaklaşık 1 ay sonra psödoanevrizma tespit edilmiştir. Sağ brakial pleksus bası bulguları izlenen, sağ kol arteriyel akımda azalma ve vena kava süperior sendromu bulguları gelişmeye başlayan hastaya sağ supraklavikuler ve median sternotomi kombinasyonu modifiye 'trapdoor' kesi ile cerrahi uyguland.

Anahtar kelimeler: Psödoanevrizma, kateter, pediatrik, subklavyen arter

\section{INTRODUCTION}

Central venous catheter usage performed by experienced staff is preferred more frequently in pediatric intensive care units (ICU). Usually puncture is performed to subclavian vein. Life threatening complications such as local hematoma, pseudoaneurysm, pneumothorax, hemothorax, arteriovenous fistula, vena cava superior syndrome, cardiac tamponade due to puncture are seen rarely ${ }^{(1,2)}$. Subclavian pseudoaneuryms should be rapidly intervened after diagnosis because of their potential risk to rupture, emboli of the distal artery and probable complications due to compression of the peripheral anatomical structures.

\section{CASE}

One year old, $5100 \mathrm{~g}$ male patient, born as a twin at $26^{\text {th }}$ gestational week, has been followed at ICU because of bronchopulmonary dysplasia and recurrent pneumonia since his birth. Approximately 1 monthago, hemorrhage was seen after right subclavian venous puncture, and was controlled by manual compression. No specific pathology was
(C) Telif hakkı T.C. Sağılık Bakanlığı İmir Tepecik Eğit. ve Araşt. Hastanesi. Logos Tıp Yayıncılık tarafindan yayınlanmaktadı. Bu dergide yayınlanan bütün makaleler Creative Commons Atf-GayriTicari 4.0 Uluslararası Lisansı ile lisanslanmıștır.

(c) Copyright Association of Publication of the T.C. Ministry of Health Izmir Tepecik Education and Research Hospital. This journal published by Logos Medical Publishing. Licenced by Creative Commons Attribution-NonCommercial 4.0 International (CC BY-NC 4.0) 
observed in control Doppler ultrasonography. In time, movement deficit was observed at the right arm followed by right supraclavicular swelling. Ultrasonography of the area showed $47 \times 31 \mathrm{~mm}$ mass related with subclavian artery; seemingly a pseudoaneurysm. Due to the following magnetic resonance imaging and thorax computed tomography report, the $5 \times 5.5 \mathrm{~cm}$ mass was a hematoma originating from right subclavian vein, at the border of vertebral artery compressing trachea; and no contrast leakage was observed (Figure 1). The mass was extending to right perihilar area. Patient was refered to our unit for treatment. Pulsation was palpated on the mass, and murmur with auscultation. Decreased blood flow was reported to the arterial structures of right arm. Control examination of the patient showed there was still pulsation on the mass, and formation of periorbital edema.

Surgery decision was made according to the findings. Full consent for surgical procedure and academic purposes was taken from the parents before surgery.

Modified 'trapdoor' incision was performed by adding right supraclavicular incision to mid- sternotomy incision (Figure 2). It was seen that the aneurysm sac was extending to suprasternal notch. Right lung was reaching left hemithorax, covering pericardium. Thymus gland was resected. Aneurysm sac was fibrotic and observed as adherent to all of the peripheral tissues. Platysma muscle was divided on supraclavicular portion of the sac. Vagus and phrenic nerves were identified and preserved. Anterior scalene and sternocleidomastoid muscles were dissected and divided. As the sac's periphery became more visible, right carotid artery was observed. Brachiocephalic trunk and proximal right subclavian artery were found. They were divided from the sac and taped. Sac's transverse length was measured as $6-7 \mathrm{~cm}$. Right innominate, subclavian and internal jugular vein were found out to be deviated laterally and collapsed. Those were divided from the sac and relieved. Right subclavian artery could be tracked for $1 \mathrm{~cm}$ after the bifurcation; its branches could not be identified. In a further step the artery's course inside the sac was realized. However its distal part could not be observed and divided from the sac. After systemic heparinization, proximal subclavian artery was clamped; as the distal part could not be assessed we were obliged to clump it with the peripheral tissues. Aneurysm sac
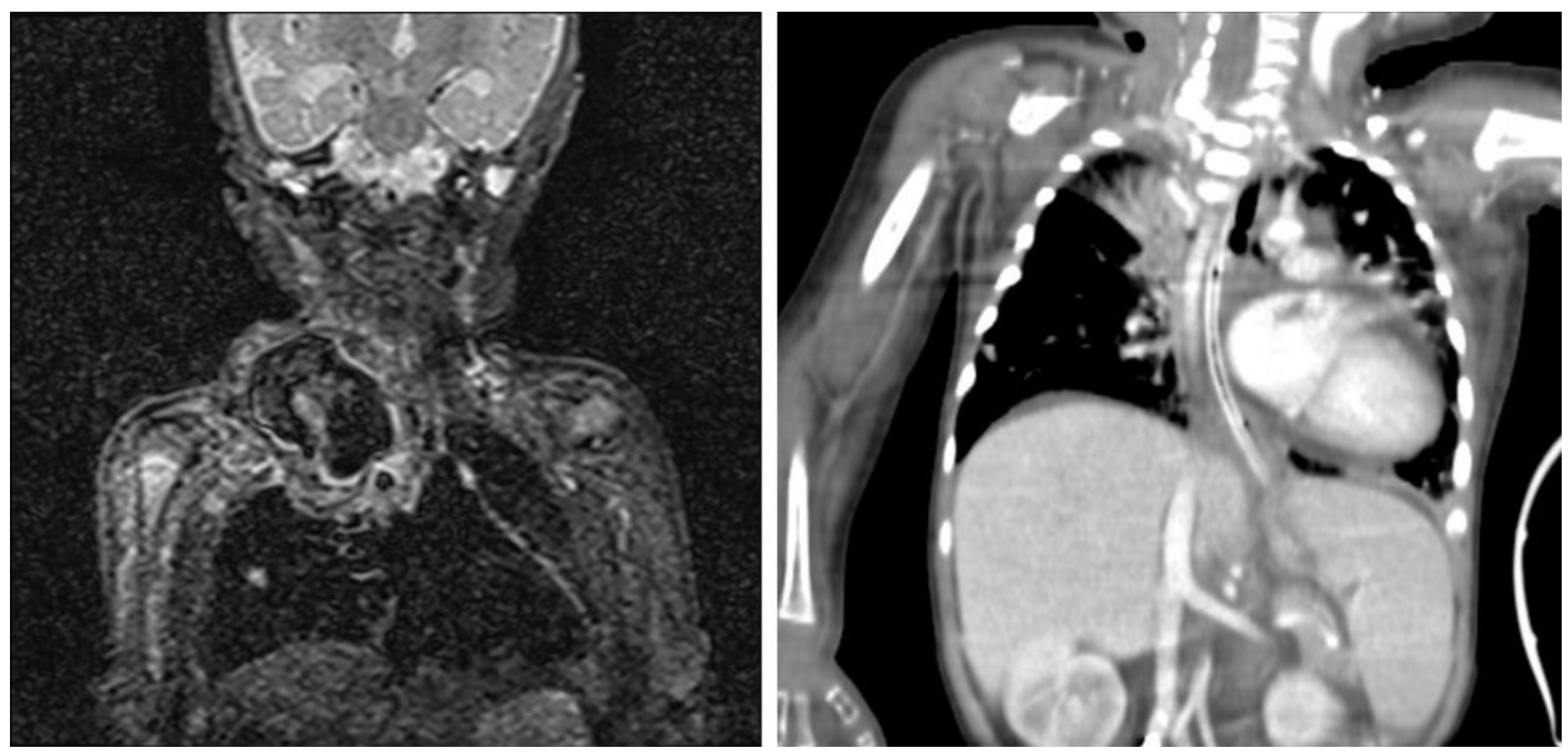

Figure 1. Case's preoperative MRI and postoperative CT images. 

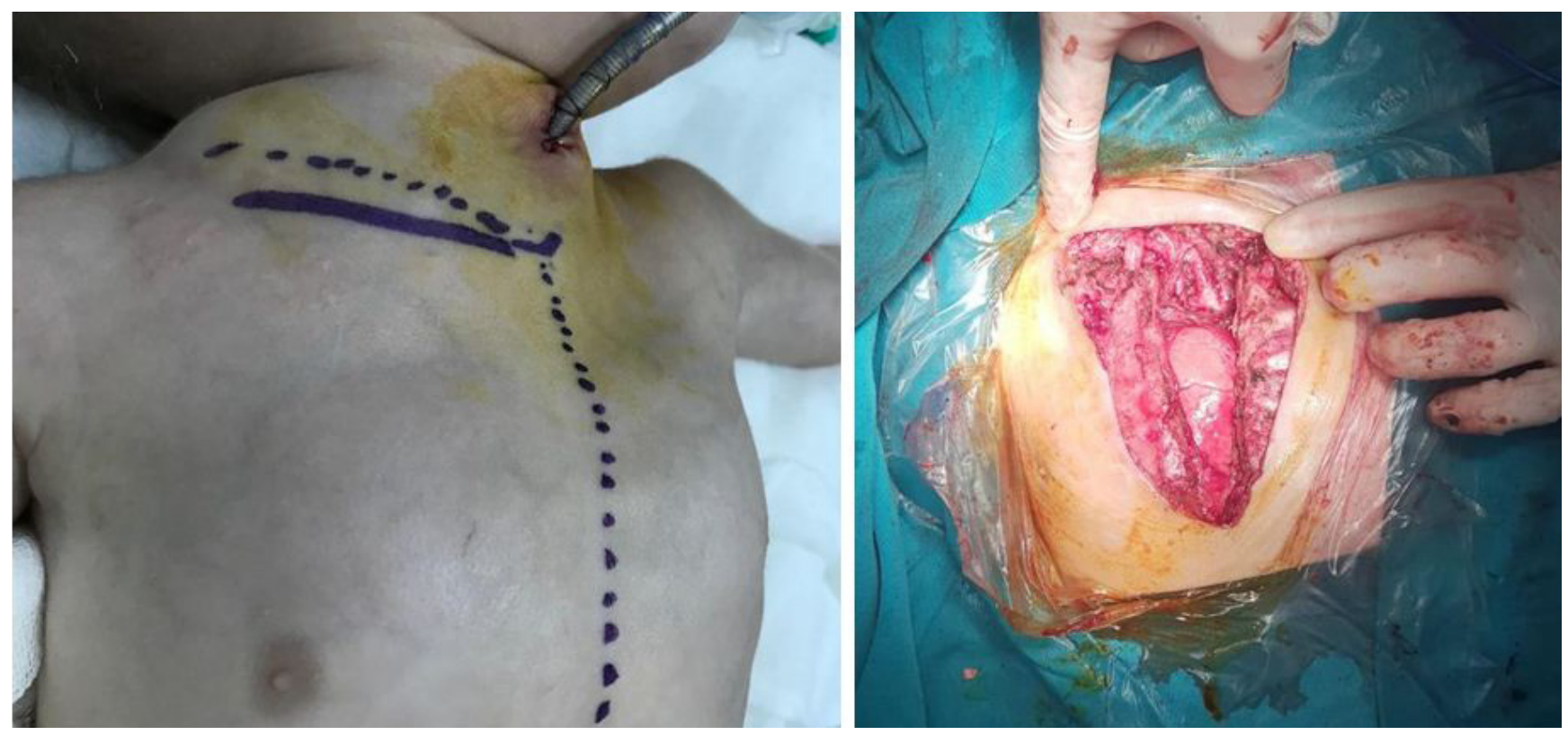

Figure 2. Incision's borders and perioperative exposure.

was cut and opened. Organized hematoma was removed from the sac. Two rupture sites of $5 \mathrm{~mm}$ were found, and suturated with $6 / 0$ prolene. Clamps were opened. Hemorrhage was seen at distal clamp site, and repaired primarily. Since blood flow distal to the pseudoaneurysm could not be assessed manually, right upper extremity was examined with Doppler probe; flow was observed. The sac was not resected due to its adhesions to all of the peripheral tissues.

\section{DISCUSSION}

Central venous catheter procedures are performed at pediatric ICUs when peripheral vascular access fails for the hemodynamic monitorization, and for the multiple infusion therapies that are needed. Practical anatomical access does give a preference to the subclavian vein ${ }^{(3)}$.

Catheterization procedures are difficult in the pediatric population, and demands more experience. Arterial puncture is seen frequently as up to $20 \%$ during the procedure ${ }^{(2)}$. Even though arterial puncture is observed more frequently in internal jugular procedures, subclavian artery injuries tend to cause more severe complications. Pseudoaneurysm formation is observed in 1-4 weeks after arterial injury ${ }^{(4)}$. If arterial injury is suspected during the procedure, clinical follow-up of the area is essential. In our case, early control ultrasonography was performed, and even though any pathological sign was not observed at that time, complications were determined after 1 month leading to diagnosis.

Ultrasonography is usually used for pseudoaneurysm diagnosis, and it is generally sufficient. In order to identify the pseudoaneurysm sac's entrance and to plan surgery, MRA, BTA and digital subtraction angiography could also be used ${ }^{(5)}$.

Pseudoaneurysms can also be cured with endovascular stent procedures and thrombin injection to the site. There is less experience about these procedures for the pediatric patient group. For subclavian artery, surgery should be the therapy of choice rather than the endovascular procedures, because the vertebral artery branch which contributes to the cerebral perfusion originates from there, and endovascular procedures may cause serious complications ${ }^{(6)}$.

Subclavian pseudoaneurysms may present with 
symptoms of compression to the peripheral structures. Loss of sensation, weakness and movement disabilities because of brachial plexus compression, vena cava superior syndrome due to compressed large venous structures, and paralysis or ischemia of extremities due to distal arterial compression can be observed ${ }^{(7)}$. In our case, first symptoms were due to brachial plexus compression followed by vena cava superior syndrome and arm ischemia symptoms were observed. The therapy choice should also be surgery and relaxation of the anatomical structures in the area for the patients with compression symptoms. Endovascular procedures should not be performed even though the site is suitable.

Access to subclavian pseudoaneurysm through surgery can be done via supraclavicular single incision, or combined incision with median sternotomy. Especially for the right sided lesions, it is stated that mid-sternotomy allows better control of vessels proximal parts. Removing clavicle's sternal tip is also a fine maneuver for increased control of the site. For the left sided lesions, proximal control can be achieved by anterolateral or posterolateral thoracotomy ${ }^{(8)}$.

In conclusion, even though pseudoaneurysm formation is a rare complication after catheter placement, it can cause serious consequences. We recommend USG guided puncture to avoid these complications. If there is a suspicion of arterial puncture, long interval compression and changing the puncture site for further injuries should be suitable. And also after that, USG follow-up of the site for pseudoaneurysm formation is recommended. We believe that sooner the diagnosis is made, the easier surgery will be performed, and less complications will occur.

Conflict of Interest: None.

Informed Consent: It has been taken.

\section{REFERENCES}

1. Robert TB, Derek R, Kieta BA, Michael WG. Complicated right subclavianarterypseudoaneursymaftercentralvenipuncture. Ann Thoracis Surg. 1996;62:581-2. [CrossRef]

2. Meloni T, Carbonatto P, Rossi G, Aillon C, Marti G, Devoti G. Percutaneous embolization of subclavian pseudoaneurysmatic arteriovenous iatrogenic fistula by steel coils. J Cardiovasc Surg. 1993;34:87-9.

3. Akyıldız B, Kondolot $M$, Akçakuş $M$, et al. Çocuk yoğun bakım ünitesinde santral venöz kateterizasyon uygulanan hastalarımızın değerlendirilmesi: iki yıllık deneyimlerimiz. Çocuk Sağlığı ve Hastalıkları Dergisi 2009;52:63-7.

4. Najafi A, Moharari RS, Khajavi MR, Salimi J, Khashayar P. A giant subclavian pseudoaneurysm following centra Ivenous catheterization. J Anesth. 2009;23:628-9. [CrossRef]

5. Coughlin B, Paushter D. Peripheral pseudoaneurysms: evaluation with duplex us. Radiology 1988;168:339-42. [CrossRef]

6. May J, White GH, Harris PJ. Endovascular repair: a beter option for treatment of complex false aneurysm. Aust N Z J Surg. 1998;68:29-34. [CrossRef]

7. Tarng DC, Huang TP, Lin KP. Brachial plexus compression due to subclavian pseudoaneurysm from cannulation of jugular vein hemodialysis catheter. American Journal of Kidney Diseases 1998;31:694-7. [CrossRef]

8. Erentuğ V, Mansuroğlu D, Tuncer A, Rabuş MB, Uyar I, Dağlar B. İyatrojenik tiroservikal yalancı anevrizma. Türk Göğüs Kalp Damar Cer Derg. 2001;9:265-7. 